\title{
BLOOMING AND FLOWER MORPHOLOGY OF CAMELLIA HIEMALIS GROWN UNDER WARMER CONDITION
}

\author{
Atsushi NAKASHIMA ${ }^{1}$, Tatsuya KUSHIDA ${ }^{2}$, Takeshi TOKURA ${ }^{3}$, Shiro NAKAO $^{4}$, \\ Hiroyuki YAMADA $^{5}$, Katsumasa MATSUMOTO ${ }^{6}$, Kazushi YAMADA $^{7}$ and Shinobu YABU ${ }^{8}$ \\ ${ }^{1}$ Member of JSCE, Ph D., Associate Professor, Dept. of Env. Sys., University of Wakayama \\ (930 Sakaedani, Wakayama-city, Wakayama 640-8510, Japan) \\ 2 Ph D., Research Engineer, Japan Academy of Ecological Education, Kubiki Village \\ (116-1 Hinetsu, Kubiki-mura, Niigata 942-0192, Japan) \\ 3 Student, Dept. of Env. Sys., University of Wakayama \\ (930 Sakaedani, Wakayama-city, Wakayama 640-8510, Japan) \\ ${ }^{4}$ Member of JSCE, Dr. Agr., Assistant Professor, Dept. of Env. Sys., University of Wakayama \\ (930 Sakaedani, Wakayama-city, Wakayama 640-8510, Japan) \\ 5 Member of JSCE, Dr. Agr., Assistant Professor, Dept. of Env. Sys., University of Wakayama \\ (930 Sakaedani, Wakayama-city, Wakayama 640-8510, Japan) \\ 6 EX Associate Professor, Center for Joint Research and Development, University of Wakayama \\ (930 Sakaedani, Wakayama-city, Wakayama 640-8510, Japan) \\ ${ }^{7}$ Chief Research Engineer, Japan Greenery Research and Development Center \\ (1-9-13 Akasaka, Minato-ku, Tokyo107 \pm 0052 , Japan) \\ 8 Member of JSCE, Dr. Agr., Professor, Dept. of Env. Sys., University of Wakayama \\ (930 Sakaedani, Wakayama-city, Wakayama 640-8510, Japan)
}

\begin{abstract}
We investigated the blooming period and the morphology of the flowers in Camellia hiemalis for the plants grown under several controlled temperature conditions of the outdoor temperature altered by $+4.5^{\circ} \mathrm{C}$, $+3.0^{\circ} \mathrm{C},+1.5^{\circ} \mathrm{C}, \pm 0.0^{\circ} \mathrm{C}$ and $-1.5^{\circ} \mathrm{C}$. The results showed that the blooming period began earlier under cool conditions. There were a greater number of fruitful flowers under warmer conditions, with a greater number of petals and stamen, and longer pistils. Thus, the development of flower buds was encouraged but resulted in inhibited sprouting under warmer conditions. It was thought that the blooming period and morphology of the flowers of Camellia hiemalis should change under warmer conditions.
\end{abstract}

Key Words: global warming, blooming, morphology of the flower, Camellia hiemalis

\section{INTRODUCTION}

In recent years, attention has been drawn to the effects of global warming, such as significant changes to certain environmental conditions and effects on the growth and phenology of many living beings 1), 3)-6), 8), 10)-14). The earth's ecosystem, agricultural management and human lives are expected to change as a result of these effects. The human contribution to global warming must be halted. However, it is suspected that we do not really know the full range of effects of global warming, and further research must be conducted in order to manage wilderness 


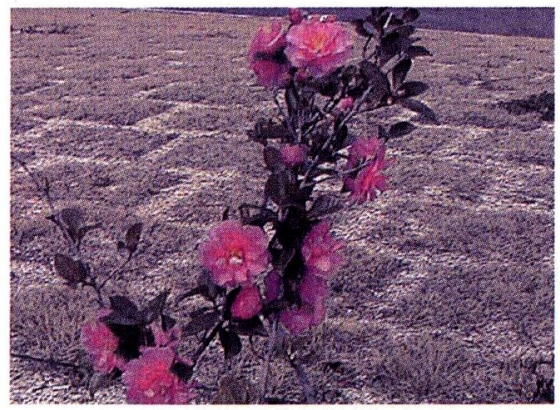

Photo.1 Flowers of Camellia hiemalis (23rd. Mar 2000)

areas properly.

Several researchers of the physiology of woody plants have mentioned that global warming will affect tree growth, morphology and phenology. Following several experiments into temperature control, Nakashima, Nagata and Kushida concluded that global warming will exert considerable effects on growth patterns and sprouting of tree buds 3), 4), 10)-14).

Similar conclusions have been drawn by other authors 2), 5)-9). However, the temperature control experiments conducted by these authors utilized conditions that do not exist in nature, for example constant temperatures of $25^{\circ} \mathrm{C}$ These results may therefore not lead to prognostications reliable or accurate enough to allow ecological engineers to monitor and manage real environments.

In this paper, Camellia hiemalis (Photo 1) were grown under three variations of warm conditions, by adding $1.5^{\circ} \mathrm{C}, 3.0^{\circ} \mathrm{C}$ and $4.5^{\circ} \mathrm{C}$ to outdoor air temperature conditions in real time, in order to determine the effects of warming on blooming behavior and flower morphology. This paper provides more usable information for $C$ hiemalis growth than previous works 2), 8)-10), 12), because the experimental conditions more closely resembled natural scenarios than past works.

$C$ hiemalis represents a favorable species for examining the effects of heat conditions from summer to autumn on the growth of buds without dormancy. The effects of warming during this period will be shown by flower morphology of $C$ hiemalis 2), 8)-10),12). Many people in Japan

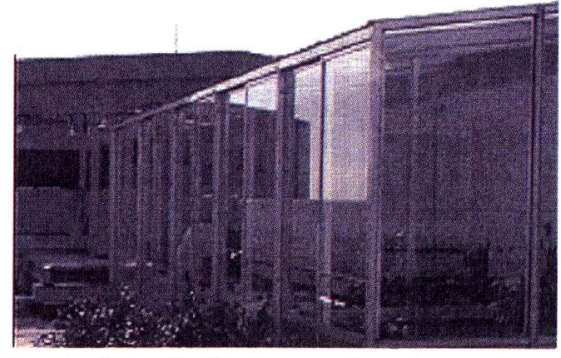

Photo.2 Growth chambers used for the experiment

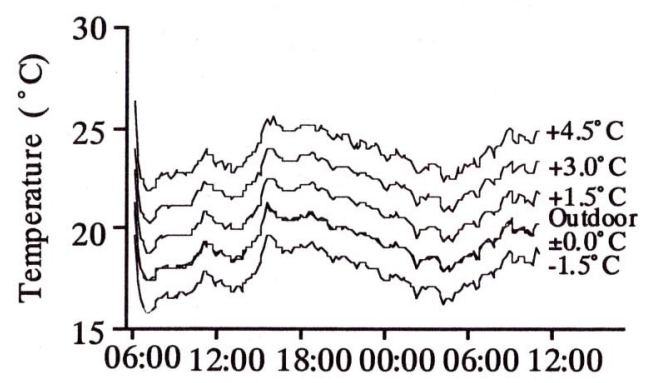

Hours ( May 25-26, 1999)

Fig.1 Temperature conditions of growth chambers and outdoor

would easily recognize a level of warming by observing blooming behavior and morphology of $C$ hiemalis, as this species is present over a large area of Japan.

\section{MATERIALS AND METHODS}

Five-year-old cuttings of $C$ hiemalis were grown in five growth chambers (Photo2) at temperatures altered from outdoor temperatures by $+4.5^{\circ} \mathrm{C}$, $+3.0^{\circ} \mathrm{C},+1.5^{\circ} \mathrm{C}, \pm 0.0^{\circ} \mathrm{C}$ and $-1.5^{\circ} \mathrm{C}$ in real time (Fig.1) from July 3rd, 1999 to August 31st, 2000. Plants were potted in vinyl pots of diameter $15 \mathrm{~cm}$ in peat moss and granite soil (1:1 by volume). Each growth chamber contained five test plants. Test plants were grown in the south-most rows of growth chambers, and were positioned without crowding each other to remove the effects of different setting position in growth chambers.

Flowers were counted every five days. The number of petals, number of petals with stamen, number of stamen, length of pistil and length of petals of all flowers were also recorded. 


\section{RESULTS AND DISCUSSION}

\section{(1) Blooming period}

Fig.2 shows blooming behavior as a blooming percentage under each temperature condition. Flower buds of the test plants began to bloom on November 22nd under the $-1.5^{\circ} \mathrm{C}$ and $\pm 0.0^{\circ} \mathrm{C}$ conditions. Blooming began on December 9th, 24th and January 12 th under the $+1.5^{\circ} \mathrm{C},+3.0^{\circ} \mathrm{C}$ and $+4.5^{\circ} \mathrm{C}$ conditions, respectively.

Table 1 shows the commencement of blooming and the results of Duncan's test to compare conditions resulting in faster blooming cycles than plants under the $-1.5^{\circ} \mathrm{C}$ and $\pm 0.0^{\circ} \mathrm{C}$ conditions. Blooming commenced earlier under cooler conditions and later under the warmer conditions. The difference between the commencements of blooming was 39 days between the $\pm 0.0^{\circ} \mathrm{C}$ and $+4.5^{\circ} \mathrm{C}$ conditions. From these results it is concluded that the commencement of blooming is delayed under warmer conditions.

The end of the blooming period under the $-1.5^{\circ} \mathrm{C}$ condition was on March 13th. The blooming period ended on March 2nd, 3rd, February 14th and March 3rd under the $\pm 0.0^{\circ} \mathrm{C}$, $+1.5^{\circ} \mathrm{C},+3.0^{\circ} \mathrm{C}$ and $+4.5^{\circ} \mathrm{C}$ conditions, respectively.

The lengths of the blooming periods were 112 ,

Table1 Date of commencement of blooming

\begin{tabular}{cccc}
\hline & Commencement & $10 \% 1)$ & $\begin{array}{c}\text { Result of } \\
\text { Duncan's test }{ }^{2}\end{array}$ \\
\hline$-1.5^{\circ} \mathrm{C}$ & Dec. $4 \pm 10.6$ & Dec. $12 \pm 15.9$ & a \\
$\pm 0.0^{\circ} \mathrm{C}$ & Dec. $4 \pm 6.9$ & Dec. $7 \pm 7.7$ & a \\
$+1.5^{\circ} \mathrm{C}$ & Dec. $26 \pm 19.4$ & Jan. $1 \pm 16.8$ & b \\
$+3.0^{\circ} \mathrm{C}$ & Jan $.2 \pm 8.8$ & Jan. $10 \pm 5.1$ & b c \\
$+4.5^{\circ} \mathrm{C}$ & Jan. $12 \pm 0.8$ & Jan. $13 \pm 3.0$ & c \\
\hline
\end{tabular}

Note :1) Date of reached at $10 \%$ of blooming percentages.

2) Duncan's test were calculated to compare the time between the temperature conditions by using the data from commencement to reached at $10 \%$ of blooming percentage $(a<b<c$ time in order, $P \leqq 0.05$ ).

Days after the first blooming and date
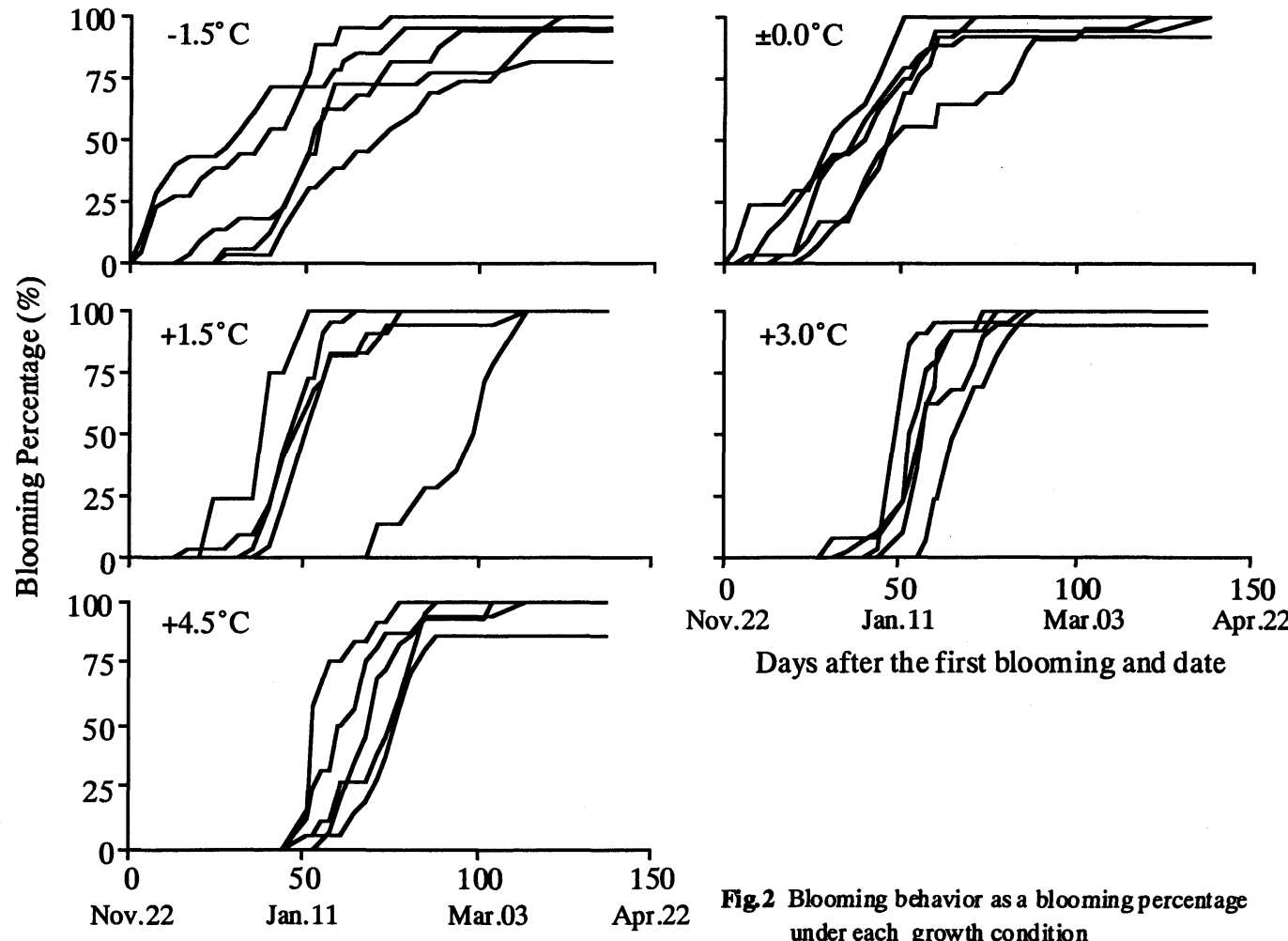

Days after the first blooming and date
Fig.2 Blooming behavior as a blooming percentage
under each growth condition
Note : Temperature conditions as shown in Fig.1 

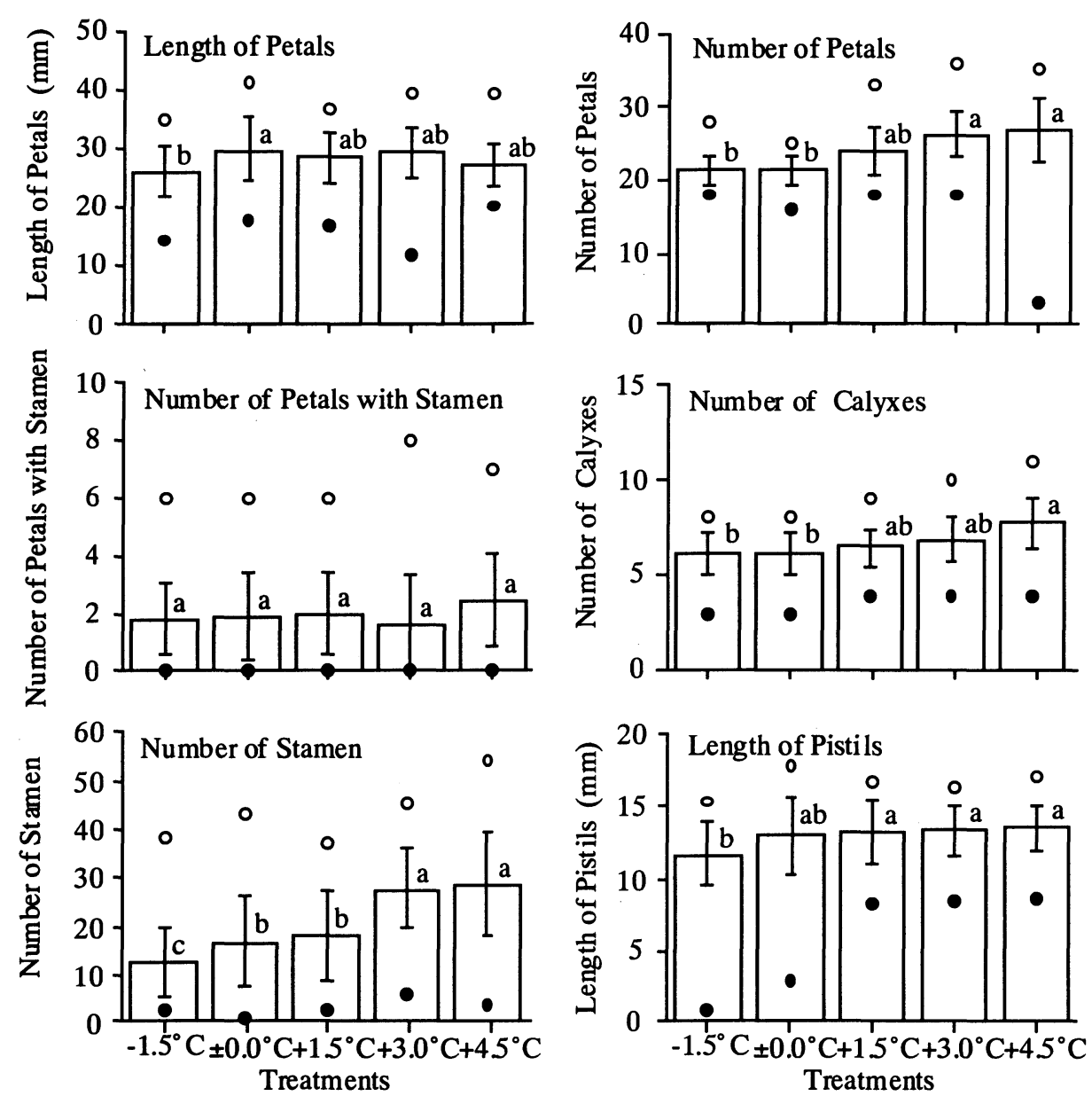

Fig.3 The morphology of the flowers for the specimens in the experiment.

Note : 1) Vertical bars show standard deviation. 2) Symbol- $\bigcirc$ show maximum value and symbolminimum value. 3 ) The $\mathrm{a}, \mathrm{b}, \mathrm{c}$ in the figure show the results by Duncan's test ( $\mathrm{a}>\mathrm{b}>\mathrm{c}, p \leqq 0.05$ )

$102,85,52$ and 51 days for the temperature conditions in increasing order. Thus, the blooming period was longer at cooler conditions. The $+1.5^{\circ} \mathrm{C},+3.0^{\circ} \mathrm{C}$ and $+4.5^{\circ} \mathrm{C}$ conditions resulted in a faster blooming cycle than that of the plants under the $-1.5^{\circ} \mathrm{C}$ and $\pm 0.0^{\circ} \mathrm{C}$ conditions. Blooming percentages of test plants were over $80 \%$ under all conditions until spring. Flower buds that failed to bloom by spring remained on the plant until early summer.

Nakashima, Kushida and Nagata have suggested that the blooming period of $C$ hiemalis may be delayed under high temperature conditions during late-summer and mid-autumn 8 ), 9). They mentioned that the growth activity of leaf buds under high temperature conditions immediately prior to the dormant state inhibits the growth of flower buds upon emergence from dormancy. Hence, flower bud growth at the end of dormancy is low under warm conditions. In the experiments in this paper, we observed this result. Warmer conditions would thus result in a delayed blooming period for $C$ hiemalis. detailed

\section{(2) Flower morphology}

Fig.3 shows the morphology of flowers for specimens in the experiment.

Greater numbers of petals were present under 
warmer conditions, and with fewer petals under cooler conditions (Duncan's test). A clear relationship between temperature conditions and length of petals was not observed, no significant differences were found in numbers of petals with stamen between conditions (Duncan's test). Greater numbers of stamen were present under warmer conditions than cool conditions (Duncan's test). Some flowers were observed to possess very few stamen under the $-1.5^{\circ} \mathrm{C}$ and $\pm 0.0^{\circ} \mathrm{C}$ conditions, including flowers that bloomed early in the blooming period. Pistil lengths under $-1.5^{\circ} \mathrm{C}$ conditions were shorter than under any other conditions (Duncan's test).

Morphology of flowers therefore changed with temperature conditions. Flowers were more fruitful under warmer conditions. Goi considered that flower bud formation in $C$ hiemalis was promoted at over $20^{\circ} \mathrm{C} 2$ ), because the growth of flower buds was highest under constant $25^{\circ} \mathrm{C}$ conditions compared to $5^{\circ} \mathrm{C}, 10^{\circ} \mathrm{C}, 15^{\circ} \mathrm{C}$ and $20^{\circ} \mathrm{C}$ conditions until mid-summer. After mid-summer, the growth of flower buds was most pronounced under constant $15^{\circ} \mathrm{C}$ conditions, and flower buds bloomed earliest under the same condition. The most favorable temperature conditions for flower bud formation, growth and blooming varied with the season. Nakashima, Kushida and Nagata 3), 4), 10)-14) and Goi 2) concluded that sprouting is independent of the development of flower buds, as many flowers without pistils were observed in their experiments. However, no flowers without petals or stamen were observed. The most favorable temperature conditions for blooming therefore differ from those for pistil growth in flower buds.

In the present study, test plants were grown under the same variable temperature conditions as the experiments of Nakashima, Kushida and Nagata and Goi 2), 9)-12). The most suitable temperature conditions for flower bud growth therefore remain unclear. However, warmer conditions would seem likely in the flowers of $C$ hiemalis being more fruitful.

\section{CONCLUSION}

Global warming is not a simple phenomenon, and involves numerous other effects in addition to simple increases in global temperature, such as altered environmental conditions of atmospheric $\mathrm{CO}_{2}$-concentrations, humidity, rainfall and solar intensity. Strictly speaking, all these effects must be understood if we are to properly manage wilderness areas during periods of rapidly changing conditions under new global warming conditions. This is, of course, a monumental task. Studies of multiple smaller effects contribute to our overall understanding of the effects of global warming.

To this end, the authors studied the effects of warming on blooming behavior and flower morphology in $C$ hiemalis. Blooming was observed to commence earlier under cooler conditions and later under warmer conditions. The length of the blooming period was shorter under warmer conditions, and flowers were more fruitful. Blooming commencement would therefore be delayed and length of blooming period shortened under conditions of increased temperatures. Such changes could act as a good indicator of climate changes in real environments.

Some researchers have suggested that warmer conditions will result in changes to the phenology of many woody plant species 1), 3)-6), 8), 10)-14). This hypothesis has certainly been substantiated in respect to the blooming of $C$ hiemalis in the present study. However, the effects on the phenology of other species remain unclear. The effects of warmer conditions on the growth of other woody plant species should be clarified to assist planning and management of wilderness areas. 


\section{REFERENCES}

1) Fujiwara, K.: Research of ecological and hereditical breeding with the earth getting warmer in temperate and northern trees, Abstracts of research project, grant-in-ade for scientific research, pp.599, 1995.

2) Goi, M.: Studies on the flower formation and forcing of some ornamental trees and shrubs native to east Asia, Memoirs of Faculty of Agriculture, Kagawa University, Vol. 38, 1-120, 1982.

3) Kushida, T., Nakashima, A. and Nagata, H.: Lammas shoot induction in Pinus densiflora by heating in spring, J.Jpn.For Soc., Vol.81, 57-64, 1999.

4) Kushida, T., Nakashima, A. and Nagata, H.:Relations between lammas shoot elongation and flowering of male and female flowers in Pinus densiflora seedlings, J.Jpn.For Soc., Vol.81, 109-115, 1999.

5) Liu, Z., Kushida, T., Nakashima, A. and Nagata, H.: Studies of External Environment Factors Inducing Apical Growth Cessation in Seedlings of Idesia Polycarpa, Environmental Engineering Research, Vol.35, 487-494, 1999.

6) Liu, Z., Nakashima, A., Kushida, T. and Nagata, H.: Effect of temperature condition in winter on the terminal buds sprouting in Idesia polycarpa., Environmental Systems Research, Vol.26, 239-244, 1999.

7) Nagata, H., Nakashima, A. and Yurugi, Y.: Bud dormancy of woody plants (I), Reprinted from Bulletin of the Mie Univ. Forests, Vol.18, 17-42, 1994.

8) Nakashima, A., Funakoshi, S. and Nagata, H.: Effects of horizontal and vertical transferring on flowering in
Camellia sasanqua, Research papers of Japan Forest Society, Vol.106, 319-322, 1995.

9) Nakashima, A. and Nagata, H.: Effects of constant temperature after the spring flush on the flowering and lammas shoot formations of Camellia hiemalis Nakai, J.Jpn.For Soc., Vol.77, 254-259, 1995.

10) Nakashima, A., Yabu, S., Kushida, T. and Nagata, H.: Relationships between lammas shoot and flower bud formation in Camellia hiemalis Nakai, J.Jpn.For Soc., Vol.79, 69-75, 1997.

11) Nakashima, A., Yabu, S., Kushida, T. and Nagata, H.: Effect of the chilled treatment on the flowering of Phlox subulata L., J.Jpn.Soc. of Rev.Tec, Vol.23, 20-25, 1997.

12) Nakashima, A., Yurugi, Y. and Nagata, H: Effects of temperature and photoperiod in the summer on flowering of Camellia hiemalis Nakai, J.Jpn.For Soc, Vol.76, $584-589,1994$

13) Nakashima, A., Yabu, S., Nakao, S. and Nagata, H.: Regional and yearly changes of flowering date in Prunus yedoensis studied for the observation by the Japan Meteorological Agency, Environmental Systems Research, Vol.25, 7-12, 1997.

14) Nakashima, A., Kushida, T., Yabu, S. and Nagata, H.: Effects of winter chilling on the flowering and shoot elongation of Rhododendron indicum Sweet, Environmental Engineering Research, Vol.35, 477-485, 1998.

(Received September 18,2000$)$

\title{
温暖化条件下で生育させたサザンカ ‘獅子頭” の開花と花の形態
}

\author{
中島敦司・櫛田達矢・十倉武司・中尾史郎・ \\ 山田宏之・松本勝正・山田和司・養父志乃夫
}

温暖化条件下におけるサザンカ ‘獅子頭’ の開花と花の形態の違いを調べるため, 供試植物を野外の気温と 常にリアルタイムで $-1.5^{\circ} \mathrm{C}$, 全く同じ, $+1.5^{\circ} \mathrm{C},+3.0^{\circ} \mathrm{C}, 4.5^{\circ} \mathrm{C}$ 変化させたグロースチャンバーの中で育成し た. その結果, 供試植物の開花は温度が高くなるにしたがって遅れることが明らかとなった，反面，高温条件 下で育成した供試植物に着生した花の形態は，野外と同じ温度条件下のものよりも充実していた，以上の結果， 地球温暖化にともなう温暖上昇した条件下では，開花前の花芽の発育は促進されるものの，花芽の展開すなわ ち開花は遅れるものと考えられた. 